\title{
The MFCMA-MMPA-ESA Reauthorizations: Incremental Fine Tuning versus Holistic Solutions ${ }^{1}$
}

M. Casey Jarman ${ }^{2}$

William S. Richardson School of Law, University of Hawaii

Richard G. Hildreth

University of Oregon Ocean and Coastal Law Center

Jamie Marthaler

University of Baltimore School of Law

\section{INTRODUCTION}

During the 103d Congress, whose term ended in 1994, three important pieces of U.S. ocean legislation were scheduled for reauthorization: the Magnuson Fishery Conservation and Management Act (MFCMA), Marine Mammal Protection Act (MMPA), and Endangered Species Act (ESA). The MMPA, MFCMA, and marine aspects of the ESA are administered by the National Marine Fisheries Service (NMFS) of the National Oceanic and Atmospheric Administration (NOAA) in the cabinet-level U.S. Department of Commerce. ${ }^{3}$ Congress first passed these laws during what has come to be known in the United States as the environmental decade-roughly the late 1960s through the late 1970s. They were the "ocean" part of an emerging national vision based on the realization that we were abusing the natural resources upon which our prosperity is based and a belief that benign federal intervention could slow most of the needless and wasteful resource destruction. The vision was of a world where overfishing would cease, marine mammal populations

1. This paper is the result of research sponsored in part by Oregon Sea Grant with funds from NOAA Office of Sea Grant, Department of Commerce, under NA Grant No. NA36RG0451 (Project R/PPA-38). The coauthors also gratefully acknowledge the research assistance of Andrea Coffman and the manuscript assistance of Nancy Farmer of the University of Oregon Ocean and Coastal Law Center.

2. M. Casey Jarman dedicates this article to the memory of Dr. James Jones, former director of the Mississippi-Alabama Sea Grant Consortium, who supported and encouraged her work for many years.

3. See National Marine Fisheries Service, Strategic Plan for the Conservation and Wise Use of America's Living Marine Resources (Washington, D.C.: GPO, 1991); National Oceanic and Atmospheric Administration, 1995-2005 Strategic Plan (Washington, D.C.: GPO, 1993).

(C) 1994 by The University of Chicago. All rights reserved. 0-226-06614-2/94/0011-0014\$01.00 
would recover, plant and nonhuman animal species would be returned from the brink of extinction, habitat destruction would be curtailed, and pollution would be reduced to "safe" levels. ${ }^{4}$

In retrospect, missing from the vision was the recognition that natural resources, including those in the ocean, cannot be sufficiently protected or successfully managed in isolation from one another. Fish, marine mammals, sea turtles, marine birds, corals, and other marine organisms exist as parts of complex ecosystems. Each law was passed with scant notice of the impact it would have on the others. ${ }^{5}$ Recent experience has proven the weakness in this vision. The Marine Mammal Commission's 1992 Report to Congress documents the extensive problems that marine mammals continue to face, even with protection afforded by the ESA and MMPA. Thus, the issues discussed in this paper involve concrete attempts to work out conflicting uses of ocean space and resources between human interests-for example, pollack fishers and Steller sea lions-through such techniques as buffer zones, to avoid losing biological diversity. ${ }^{6}$

Respected ocean-policy scholars have condemned Congress's "single legislation" approach to ocean resource protection management and have called for a more integrated approach. ${ }^{7}$ With three key ocean resource bills up for reauthorization, the $103 \mathrm{~d}$ Congress has the opportunity to take a more holistic approach specifically accounting for their interactions. Whether a more holistic approach will be taken as part of the reauthorization process remains to be seen. 8

In light of the important interests at stake and the opportunity for immediate congressional action, we studied such interactions under the MFCMA,

4. Magnuson Fishery Conservation and Management Act, U.S. Code Annotated, vol. 16 (1985, Supp. 1993), Sec. 1801; Marine Mammal Protection Act, U.S. Code Annotated, vol. 16, Sec. 1361 (1985); Endangered Species Act, U.S. Code Annotated, vol. 16, Sec. 1531 (1985, Supp. 1993); Clean Water Act, U.S. Code Annotated, vol. 33, Sec. 1251 (1985); Clean Air Act, U.S. Code Annotated, vol. 42, Sec. 7401 (1985, Supp. 1993); Marine Protection, Research, and Sanctuaries Act of 1972, U.S. Code Annotated, vol. 33, Sec. 1401 (1985).

5. The tuna-dolphin conflict in the purse-seine tuna fishery of the eastern tropical Pacific was raised in the hearings on the original MMPA, but detailed legislation to deal with the problem was not passed until the MMPA was amended in 1981. And Section 1543 of the ESA states that the more restrictive provisions of the MMPA take precedence over the ESA.

6. Susan D. Halsey and Robert B. Abel, eds., Coastal Ocean Space Utilization (New York: Elsevier, 1990); Phyllis M. Grifman and James A. Fawcett, eds., International Perspectives on Coastal Ocean Space Utilization (Los Angeles: Sea Grant Program, University of Southern California, 1993).

7. Biliana Cicin-Sain, ed., Ocean Governance: A New Vision (Newark: University of Delaware, 1992).

8. It is somewhat ironic that all three acts formerly were handled by one House of Representatives subcommittee, which would seem to have increased the opportunities for a more holistic congressional approach, but the MFCMA has now been assigned to a separate fisheries subcommittee. 
MMPA, ESA, and Migratory Bird Treaty Act (MBTA), with primary focus on incidental take of marine animals in the course of commercial fishing operations. The MBTA is included because migratory marine birds are incidentally taken in large numbers in certain commercial fisheries. This paper explains the complex network of incidental-take provisions of the MMPA, ESA, and MBTA and shows where and how they interact. It then reviews and critiques the NMFS and MMPA Negotiating Group's proposals for amending the incidental-take provisions and describes current real-world interactions. The paper ends by concluding that a more holistic approach to protection and management of marine resources is needed but unlikely to be successfully implemented, given the mobility of the marine species of concern, the fluid nature of their environment, the mixed track record of the federal agencies charged with their protection and management, and congressional inability to legislate in other than a piecemeal fashion. Achieving the original vision of a healthy and diverse ocean ecosystem that can provide a steady food source and economic opportunities remains problematic.

\section{OVERVIEW OF THE MFCMA, ESA, MMPA, AND MBTA}

\section{Magnuson Fishery Conservation and Management Act}

The MFCMA establishes a management scheme designed to regulate domestic and foreign fishing within the U.S. 200-mile exclusive economic zone through development of management plans for the various fisheries that require management. The mechanism established to draft these plans is the regional management council, a unique creation of the MFCMA that is designed to represent federal, regional, state, and local interests in the decisionmaking process. Eight regional fishery management councils have been established to cover the U.S. exclusive economic zone. Each council must conform the provisions of its fishery management plans to seven national standards aimed at effective conservation of fishery resources. Each fishery management plan must, in addition, be approved by the secretary of commerce. Theoretically, about $20 \%$ of the world's fisheries are subject to this scheme.

The MFCMA has been a success as far as domesticating formerly foreign fisheries, but it is generally recognized as a failure with respect to conservation of fish species and protection from overfishing. The waste involved in many fisheries in discards of targeted species and incidental catch of nontargeted fish and other nonmarine mammal species also are significant issues calling for congressional attention beyond the current focus on marine mammal incidental catch. ${ }^{9}$

9. See Christopher M. Dewees and Edward Ueber, eds., Effects of Different Fishery Management Schemes on Bycatch, Joint Catch, and Discards (La Jolla: Sea Grant College, University of California, 1990); Frowle, Fish for the Future: A Citizen's Guide to Federal 
Endangered Species Act

The ESA reflects a national policy favoring biodiversity. It seeks to prevent the extinction of species that are endangered or threatened, by severely restricting the circumstances under which such species can be intentionally or unintentionally taken. ${ }^{10}$ The law has been in a state of constant evolution since its inception in 1966. ${ }^{11}$ Today, the secretary of the interior is charged with listing and delisting animals for the purpose of providing protection to species in immediate danger of extinction and with providing nationwide protection for animals endangered or threatened. Once a species is no longer considered endangered or threatened, it may be removed from the list. ${ }^{12}$

Section 9 of the ESA makes it unlawful for any person subject to the jurisdiction of the United States to take, import, export, possess, sell, deliver, carry, transport, or ship any species listed as endangered. Section 7 prohibits federal agencies from carrying out activities that will be likely to "jeopardize the continued existence of any endangered species or threatened species or result in the destruction or adverse modification of habitat of such species ... determined . . . to be critical." ${ }^{13}$ The "incidental take" provisions, which first

Fisheries Management (Center for Marine Conservation, 1992); National Marine Fisheries Service, Our Living Oceans: The Status of U.S. Living Marine Resources (Silver Spring, Maryland: National Marine Fisheries Service, 1992).

10. Take is defined as "to harass, harm, pursue, hunt, shoot, wound, kill, trap, capture, or collect, or to attempt to engage in any such conduct" (Endangered Species Act [n. 4 above], Sec. 1532 [19]).

11. As the first comprehensive endangered-species legislation, the ESA had two objectives: to authorize the secretary of the interior to create programs that promote the propagation of native fish and wildlife threatened with extinction, and to expand administrative authority of the secretary over the National Wildlife Refuge System (Act of 20 December 1973, Public Law 93-205, U.S. Code Congressional and Administrative News (1973): 2989, 2990). The act was expanded to authorize the development of a list of species threatened with worldwide extinction and to prohibit the importation of such animals or of products made from the animals. This measure was designed to help ensure that the United States would not contribute to the degradation of other nations' wildlife (p. 2991). An exception to this restriction was created, allowing the importation of threatened animals for scientific, educational, zoological, or propagational purposes. It also amended existing legislation to assist the states in protecting domestically endangered species by making the sale or purchase of endangered species products unlawful throughout the United States.

12. For example, the threatened eastern North Pacific stock of the gray whale was delisted in December 1992. The NMFS determined that the gray whale population is "between 60 and 90 percent of its carrying capacity" and "is not currently in danger of extinction" (Federal Register 56 [1991]: 29472). Most other listed species have not recovered sufficiently to be delisted.

13. Endangered Species Act (n. 4 above), Sec. 1536(a)(2). Exemptions from this requirement are available by following a complicated exemption process. See Sec. $1536(\mathrm{~b})-(\mathrm{p})$. 
appeared in the 1982 amendments, established a procedure for persons whose actions may affect endangered or threatened species to obtain permits for the incidental taking of such species if the action would not jeopardize the species' continued existence. ${ }^{14}$ It allows the secretary to permit any taking that is incidental to, and not the purpose of, an otherwise lawful activity. This exception is discussed in more detail below. Criminal and civil penalties may be imposed on violators of the ESA and its accompanying regulations.

\section{Marine Mammal Protection Act}

The MMPA works similarly to the ESA. The central mechanism to preserve marine mammals and rebuild populations is a moratorium on the taking of any marine mammal. Taking actions include attempting to or actually harassing, hunting, capturing, or killing marine mammals. Marine mammals include sea otters, polar bears, seals, whales, dolphins, porpoises, dugongs, and manatees. As with the ESA, Congress has allowed certain limited exceptions to the moratorium. In addition to the commercial-fisheries incidental-take exception discussed below, exceptions can be made by permit for scientific research, public display, enhancing the survival or recovery of a species or stock, or to Alaskan Indians, Aleuts, or Eskimos for subsistence purposes or for creating and selling native craftworks. A 1988 amendment requires status reviews of stocks designated as depleted ${ }^{15}$ and the creation of conservation plans designed to restore species or stocks to their optimum sustainable population. ${ }^{16}$ Civil and criminal penalties may be levied against violators of the MMPA.

\section{Migratory Bird Treaty Act}

The MBTA was passed in 1918 to restore bird populations in parts of the United States where they had become scarce or "extinct" and to regulate the introduction of bird species into areas they did not formerly inhabit. ${ }^{17}$ It makes illegal the attempt at or actual capturing, killing, or taking of migratory

14. Ibid., Sec. 1539.

15. A depleted stock has fallen below its determined optimum sustainable population or is listed as endangered or threatened under the ESA (Marine Mammal Protection Act (n. 4 above), Sec. 1362[1]).

16. "The term 'optimum sustainable population' means, with respect to any population stock, the number of animals which will result in the maximum productivity of the population or the species, keeping in mind the carrying capacity of the habitat and the health of the ecosystems of which they form a constituent element" (ibid., Sec. 1362[9]).

17. Migratory Bird Treaty Act, U.S. Code Annotated, vol. 16, Sec. 701 (1985). 
birds. ${ }^{18}$ An exception to the moratorium allows the secretary of the interior by regulation to determine when, and to what extent, the taking, killing, or hunting of migratory birds may occur. The MBTA contains no separate incidental-take provision. Criminal penalties may be asserted against any violator of the MBTA.

\section{INCIDENTAL-TAKE PROVISIONS}

\section{Endangered Species Act}

The incidental-take provision first appeared in the ESA's 1982 amendments in response to pressure from land-based development interests. Permits to take endangered marine species incidentally to an otherwise lawful activity are issued by NOAA and the U.S. Fish and Wildlife Service. ${ }^{19}$ Applicants must submit a conservation plan with their applications. The plan must detail the anticipated impact of the proposed activity on the species or stocks as well as on their habitat; proposed steps to mitigate such impacts and the funding available to implement mitigation measures; and alternatives to the incidental take and why they have been rejected. ${ }^{20}$ Permits may be granted only after a finding that the taking of such species will not jeopardize their continued existence. ${ }^{21}$ To make such a finding, the agency must determine that the exception was applied for in good faith; the taking will be incidental; the taking will not "appreciably reduce" the species' chance for survival and recovery; the applicant will carry out the conservation plan; the applicant will take practicable steps to mitigate the impacts associated with the incidental take; and granting of the permit will be consistent with the national policy of conserving threatened and endangered species. ${ }^{22}$ The agency sets

18. Ibid., Sec. 703 (Supp. 1993). Other prohibited activities include hunting; offering for sale; selling; offering to barter; bartering; offering to purchase; purchasing; delivering for shipment; shipping; exporting; importing; causing to be shipped, exported, or imported; delivering for transportation; transporting or causing to be transported; carrying or causing to be carried; or receiving for shipment, transportation, carriage, or export.

19. Most ESA incidental-take permits are issued by the Fish and Wildlife Service in the Department of the Interior. See Code of Federal Regulations, vol. 50, Sec. 17.22 (1992). However, for those marine species over which the secretary of commerce has jurisdiction, NOAA assumes this authority (Code of Federal Regulations, vol. 50, sec. 222.22). For a list of these species, see Code of Federal Regulations, vol. 50, Sec. 222.23(a).

20. Endangered Species Act (n. 4 above), Sec. 1539(a)(2); Code of Federal Regulations, vol. 50, Sec. 222.22(b)(5).

21. Endangered Species Act (n. 4 above), Sec. 1539(a)(2).

22. Ibid., Sec. 1539(d); Code of Federal Regulations, vol. 50, Secs. 222.22(c)(2), 17.22. Section 17.22 applies to the Fish and Wildlife Service permits and contains an additional determination for which procedures to deal with unforeseen circumstances are provided. Special regulations apply to the incidental capture of threatened sea turtles. See Code of Federal Regulations, vol. 50, Sec. 222.41, 222.72(e). 
the duration of the permit and may attach conditions to issuance of the permit. ${ }^{23}$

\section{Marine Mammal Protection Act}

Congress has recognized the possible conflict between fisheries activities and marine mammal protection since the inception of the MMPA in 1972. Section 102 of the original and current act prohibits persons engaged in commercial fisheries from using "any means or methods of fishing in contravention of any regulations or limitations, issued by the Secretary for that fishery to achieve the purposes of this Act." ${ }^{24}$ According to the legislative history, Congress was concerned with the yellowfin tuna purse seine/porpoise interactions and contemplated that such interactions would be handled through the MMPA general permit provision. ${ }^{25}$ The MMPA was amended in 1981 to specifically allow takes incidental to commercial fishing other than the yellowfin tuna industry. ${ }^{26}$ Presumably to appease those who opposed any weakening of the MMPA, Congress included a goal of reducing incidental kills and serious injuries to "insignificant levels approaching a zero mortality and serious injury rate." 27

The 1981 amendment also established an alternative incidental-take procedure that does not require a Section 104 permit. A 5-year waiver of the moratorium could be granted to those wishing to take small numbers of nondepleted marine mammals after notice and opportunity for public comment and a finding by the NMFS that such take would have a negligible impact on the species or stock. ${ }^{28}$ Significantly, the NMFS was not required to

23. Endangered Species Act (n. 4 above), Sec. 1539(a); Code of Federal Regulations, vol. 50, Sec. 222.22(d).

24. Marine Mammal Protection Act (n. 4 above), Sec. 1372(a)(5), formerly Sec. 102(a)(4), Public Law 92-522 (1972).

25. "At the current time, it appears to the Committee that the tuna fleet would be an appropriate recipient of general permits, under the authority of Section 103(i) of Title I, keyed not to specific numbers of porpoises which might be taken but to the techniques that should be used in fishing operations" (House Report No. 92-707, 92d Cong., 1st sess.).

26. Marine Mammal Protection Act (n. 4 above), Sec. 1371(a)(2), Sec. 101(a)(1) amended by Public Law 97-58, Sec. 2 (October 1981).

27. Marine Mammal Protection Act (n. 4 above), Sec. 1371(a)(2). For the yellowfin tuna purse-seine fishery, that goal would be met by using the "best marine mammal safety techniques and equipment that are economically and technologically practicable."

28. Ibid., Sec. 1371(a)(4). The NMFS retained authority to suspend or withdraw such permission during the 5-year period after making a finding, following notice and comment, that the take is having a more than negligible impact or "the policies, purposes and goals of this Act would be better served through the application of this title without regard to this subsection" (Sec. 1371[a][4][B]). 
determine that animals taken pursuant to the "small take" exception had reached their optimum sustainable population (OSP) level. ${ }^{29}$

The most significant commercial-fisheries incidental-take provision was passed by Congress in 1988. While giving lip service to the "immediate" goal of reducing marine mammal incidental kill and serious injury rates to insignificant levels approaching zero, Congress lifted the moratorium on incidental take (other than the yellowfin tuna purse-seine fishery) until 1 October $1993{ }^{30}$ In the name of gathering more and better data regarding commercial fishery/marine mammal interactions, the commercial fishing industry was given a 5-year exemption. This exemption coincided with the approaching expiration of previously issued domestic general permits and small take exceptions issued after the 1981 amendments and a court decision that the NMFS claimed would preclude them from issuing new permits. ${ }^{31}$ The 1988 exemption provisions required the NMFS to authorize incidental takes from any species or stock -including a population stock designated as depleted (other than the California sea otter). Intentional lethal taking of Steller sea lions, cetaceans, and population stocks designated as depleted was prohibited.

To qualify for the exemption, fishing vessels must be registered in the United States and have a valid MFCMA permit. In addition, vessel owners have to meet certain reporting requirements and accept observers aboard their vessels. These requirements vary from fishery to fishery. Congress ordered the NMFS to categorize fisheries as having frequent incidental take, occasional incidental take, or remote likelihood of or no incidental take. ${ }^{32}$ The

29. These amendments and the legislative history reveal the growing political power of the commercial fishing industry. Although the House Report (No. 97-228) accompanying the 1981 amendment couches the 5-year waiver procedure for "small" takes in terms of enhancing marine mammal protection by increasing reports of takes, it also reflects the growing deference to commercial fishery interests: "[T]he same lengthy regulations requiring OSP determinations and permits which are applicable to the tuna industry also apply to activities involving small numbers of incidental takes. Only a fraction of non-tuna fishermen apply for a permit because of the cumbersome procedures required under the Act. The result has been a loss of data because most of these incidental takes go unreported. This symptom of "over management" has suggested the need for a two-tiered management scheme, distinguishing significant from insignificant takes" (p. 14). Nowhere in this report does Congress focus on the illegal behavior of those fishers who failed to at least attempt to apply for a permit.

30. Marine Mammal Protection Act (n. 4 above), Sec. 1383a (Supp. 1993). Subsequently, Congress extended it to 1 May 1994.

31. Senate Report No. 100-592, 100th Cong., 2d sess.; Kokechik Fishermen's Association v. Secretary of Commerce, 839 F. 2d 795 (D.C. Cir. 1988) (holding that the NMFS could not issue permit to take Dall's porpoise because of the possibility that northern fur seals would also be taken).

32. Accompanying the categories was to be a statement of the marine mammals and approximate numbers of persons/vessels in each fishery (Marine Mammal Protection Act [n. 4 above], Sec. 1383a[b][1][A]). 
NMFS retained authority to modify by emergency regulations the numbers of incidental takes after a finding that such taking is "having an immediate and significant adverse impact on a marine mammal population stock." ${ }^{33}$ The data collected from reporting and observer programs were to be analyzed by the NMFS and the Marine Mammal Commission and made available to Congress with recommendations for guidelines to govern future incidental take in commercial fisheries and a suggested regime. Unless the 103d Congress amends the MMPA or extends the exemption, the exemption ends on 1 May 1994.

Migratory Bird Treaty Act

As mentioned earlier, the MBTA contains no specific incidental-take provision. All takes are criminalized unless the Fish and Wildlife Service has provided by rule for an exception. So far the agency has not chosen to allow takes incidental to commercial fishing. Therefore, commercial fishers can be criminally prosecuted for such takes. However, despite the known mortality rates of migratory birds incidental to commercial fishing, to date no fisher has been cited under the MBTA, and agency enforcement efforts are not directed toward such violators.

\section{Interaction of the Incidental-Take Provisions}

Table 1 illustrates how these separate incidental-take provisions interact. For marine mammals that are listed as endangered or threatened under the ESA, the ESA and MMPA incidental-take provisions both apply. Therefore, fishers who are eligible for the 1988 MMPA commercial-fisheries incidental-take exemption are not relieved of their ESA permit obligations if the marine mammal is a listed species. For marine mammals that are designated as depleted under the MMPA but not listed under the ESA as endangered or threatened, only the 1988 MMPA exemption applies. Fishers incidentally taking nondepleted marine mammals are similarly covered by the 1988 exemption. Nonbird species and nonmammal marine animals, such as sea turtles, that are endangered or threatened under the ESA, receive ESA protection only. The ESA and MBTA provisions, when considered together, create an interesting situation. Commercial fishers can apply for an ESA incidentaltake permit for endangered migratory marine birds but are afforded no legal avenue to incidentally take nonendangered migratory marine birds!

33. Ibid., Sec. 1383a(g)(1). 
TABLE 1.-INCIDENTAL TAKE

\begin{tabular}{|c|c|c|c|c|c|c|}
\hline Statutes and Regulations & $\begin{array}{c}\text { Marine } \\
\text { Mammals } \\
\text { Endangered } \\
\text { or Threatened }\end{array}$ & $\begin{array}{c}\text { Marine } \\
\text { Mammals } \\
\text { Not } \\
\text { Endangered } \\
\text { or Threatened } \\
\text { but Depleted }\end{array}$ & $\begin{array}{c}\text { Marine } \\
\text { Mammals } \\
\text { Not } \\
\text { Endangered, } \\
\text { Threatened, } \\
\text { or Depleted }\end{array}$ & $\begin{array}{c}\text { Nonmammal } \\
\text { Nonbird } \\
\text { Species } \\
\text { Endangered } \\
\text { or Threatened }\end{array}$ & $\begin{array}{c}\text { Migratory } \\
\text { Birds } \\
\text { Endangered } \\
\text { or Threatened }\end{array}$ & $\begin{array}{c}\text { Migratory } \\
\text { Birds Not } \\
\text { Endangered } \\
\text { or Threatened }\end{array}$ \\
\hline ESA Sec. 1539 & $\mathbf{x}$ & & & $\mathrm{x}$ & $\mathrm{x}$ & \\
\hline aMMPA Sec. 1371 (a) (2) & $\mathrm{x}$ & $\mathbf{x}$ & $\mathrm{x}$ & & & \\
\hline${ }^{\mathrm{a}} \mathrm{MMPA}$ Sec. 1371 (a) (4) & & & $\mathrm{x}$ & & & \\
\hline $\begin{array}{l}\text { MMPA Sec. } 1383 \text { (a) (un- } \\
\text { til } 5 / 1 / 94 \text { ) }\end{array}$ & $\mathrm{x}$ & $\mathbf{x}$ & $\mathrm{x}$ & & & \\
\hline MBTA Sec. 704 & & & & & $\mathrm{x}$ & $\mathrm{x}$ \\
\hline CFR 50, Part 13 & $\mathbf{x}$ & & & $\mathrm{x}$ & $\mathbf{x}$ & \\
\hline CFR 50, Part 17 & $\mathbf{x}$ & & & $\mathbf{x}$ & $\mathrm{x}$ & \\
\hline $\begin{array}{l}\text { CFR } 50 \text {, Part } 18 \text { Endan- } \\
\text { gered or Threatened } \\
\text { FWS }\end{array}$ & $\mathbf{x}$ & & $\mathbf{x}$ & & & \\
\hline CFR 50, Part 21 & & & & & $\mathrm{x}$ & \\
\hline CFR 50, Part 216 & $\mathrm{x}$ & & & & & \\
\hline $\begin{array}{l}\text { CFR 50, Part } 222 \text { Endan- } \\
\text { gered or Threatened } \\
\text { NMFS }\end{array}$ & $\mathbf{x}$ & & & & & \\
\hline $\begin{array}{l}\text { CFR 50, Part } 229 \text { In- } \\
\text { terim exception }\end{array}$ & $\mathbf{x}$ & $\mathbf{x}$ & $\mathbf{x}$ & & & \\
\hline
\end{tabular}

NoTE.-CFR $50=$ Code of Federal Regulations, vol. 50.

a These two provisions have been superseded by MMPA Sec. 1383(a) until 1 May 1994. 


\section{ALTERNATIVE APPROACHES}

\section{NMFS's Marine Mammal Protection Act Proposal}

Because of statutory timetables, the issue most likely to get significant congressional attention is the 1 October 1993 expiration of the 5-year exemption of commercial fisheries from the MMPA incidental-take permit requirements. To date, no ESA reauthorization bill contains amendments that are directed toward the commercial-fisheries incidental-take issue. Negotiations on a replacement regime under the MMPA are proceeding based on the NMFS's November 1992 report to Congress, Proposed Regime to Govern Interactions between Marine Mammals and Commercial Fishing Operations." ${ }^{4}$ In its report, the NMFS reiterates the "ideal" zero-mortality-rate goal established in the MMPA. ${ }^{35}$ Recognizing that an ideal is rarely if ever politically possible ${ }^{36}$ the NMFS proposes the goal of allowing only those incidental takings that do not cause marine mammal stocks to fall below OSP. ${ }^{37}$ However, because data for determining OSP for most marine mammal stocks wil not be available in the reasonably foreseeable future, the NMFS recommends use of an alternative methodology when an OSP figure is not possible: Potential Biological Removal (PBR), the maximum number of individuals that could potentially be removed without disadvantaging a stock in "biologically numeric terms." Incidental-take allocations would be based on OSP or PBR for the species or stock. These PBRs would be patterned after allocation of fish stocks under the MFCMA. The NMFS's past failures to protect fish stocks with an abundance level far exceeding most populations of marine animals renders this recommendation suspect as a tool to protect nonfish marine species.

34. National Marine Fisheries Service, Proposed Regime to Govern Interactions between Marine Mammals and Commercial Fishing Operations (Washington, D.C.: GPO, 1992); see Federal Register 57 (1992): 59832.

35. National Marine Fisheries Service, Proposed Regime (n. 34 above), p. 51. Interestingly, the NMFS interpretation of "zero mortality rate" contemplates humaninduced mortality. "The ZMRG reflects the intent of Congress to allow the mortality or continued 'take' of marine mammals incidental to commercial fishing when such interactions were considered unavoidable and would not disadvantage the involved mammal stocks" (p. 51).

36. The NMFS clearly does not embrace this ideal: "The proposal is based on NMFS' belief that the removal of animals from most, but not all, marine mammal stocks may be authorized and is not inconsistent with the purposes of the MMPA" (ibid., p. 21).

37. Ibid., pp. 10-11.

38. Ibid., pp. vi, 10-11. PBRs would be based on available data and default values of growth rates when data are insufficient. Conservative estimates of population size are to be used-but they propose use of the best, not necessarily the lowestavailable, estimate of minimum abundance for all stocks to avoid unnecessary restrictions on economic activities, with adjustments made when a stock is suspected to be declining due to factors other than direct removals. 
The NMFS then backs off from its goal of maintaining OSP: "The proposed approach is based on the belief that in some, but not all cases, incidental (not directed or intentional) removals from stocks designated as depleted under the MMPA could be allowed without further disadvantage to the stock and without significantly delaying recovery time, provided that adequate precautions are taken." ${ }^{39}$ A depleted stock is one that is below its OSP. Further reading reveals that the NMFS would allow even intentional lethal takes (despite the parenthetical in the above quoted sentence) in situations where personal safety is involved or significant adverse economic effects on fishing would result if such takes were disallowed. ${ }^{40}$

To assist in determining take levels and procedures for allocating the takes, the NMFS proposal divides fisheries into four categories. Category 1 includes fisheries that have a significant impact on any endangered, threatened, or depleted stock or have total annual takes equal to or greater than the calculated PBR. Category 2 fisheries are those that have an insignificant impact on endangered, threatened, or depleted stocks or have a significant impact on any other stocks. Category 3 fisheries interact only with nonendangered, nonthreatened, or nondepleted stocks, and their level of take has no significant impact on those stocks. Category 4 consists of nontakers. ${ }^{41}$

Vessels in categories 1, 2, and 3 would be required to register with the NMFS. Category 1 fisheries would be subject to annual monitoring and possible reduced take levels. Monitoring of category 2 and 3 vessels would be less restrictive than for category 1 fisheries. Category 3 vessels would be required to report all takes. Nontakers would have the option of registering; an incentive to registration would be protection from MMPA penalties for unauthorized taking. ${ }^{42}$ Decisions regarding allocations in each category would be made through a public review process, with judicial review of the NMFS's final decisions. ${ }^{43}$ While this scheme ranks high on the public participation scale, it could lead to an administrative morass if consensus is not achieved prior to announcement of the NMFS's final decision.

Interestingly, Congress directed the Marine Mammal Commission to develop the guidelines for determining incidental takes to have a "scientific rationale and basis" and to be based on "sound principles of wildlife management." ${ }^{24}$ Economic viability of the fisheries was not to be considered by the commission in making its recommendations. ${ }^{45}$ But Congress allowed the

39. Ibid., p. 42.

40. Ibid., pp. 69-70.

41. Ibid., pp. 73-77.

42. Ibid., p. 78.

43. Ibid., pp. $56-67$.

44. Marine Mammal Protection Act (n. 4 above), Sec. 1383a(1).

45. "By February 1, 1990, the Chairman of the Marine Mammal Commission is required to transmit to the Secretary and make available to the public recommended guidelines to govern the incidental taking of marine mammals by commercial fish- 
NMFS to consider the economic effects on the commercial fishing industry in proposing its regime. ${ }^{46}$ The NMFS does so in its proposal but recognizes that such an approach runs afoul of the Endangered Species Act: "The requirements and procedures of both the MMPA and ESA must be satisfied to lawfully take any endangered or threatened marine mammal. Therefore, even if taking depleted marine mammals could be authorized under the MMPA, taking of endangered or threatened marine mammals incidental to commercial fishing would be prohibited in many cases under the current provisions of the ESA." ${ }^{47}$ In light of this interaction, the NMFS recommends that Congress establish one procedure for incidental, intentional nonlethal, and intentional lethal takes of endangered or threatened marine mammals under both the MMPA and the ESA. ${ }^{48}$ The NMFS also recommends that the incidental-take provisions be applied to recreational fishers who sell their catch, as well as to commercial fishing vessels. ${ }^{49}$ Other provisions provide for a stock assessment and research process and user fees. ${ }^{50}$

\section{MMPA Negotiating Group Proposal}

In June 1993 an MMPA Negotiating Group formed by members of the conservation and fishing communities ${ }^{51}$ published its "Conservation and Fishing

ermen after October 1, 1993. Because the MMC is a scientific body, the Committee intends that these guidelines be scientific in nature; that is, they should not deal with the economics of fisheries or allocation of fishing privileges. Further, they must be based on sound principles of wildlife management and must only be issued after full consultation with all interested parties" (Senate Report No. 100-592 [n. 31 above]). As recognized by the NMFS report, though, the Marine Mammal Commission's guidelines sanction "incidental taking of depleted species (when such taking would not prevent or cause a significant delay in the recovery of those stocks) and non-depleted species to (1) allow the ecologically sound utilization of other resources and (2) help obtain data required to manage marine mammals and marine ecosystems effectively" (National Marine Fisheries Service, Proposed Regime [n. 34 above], p. 9).

46. Marine Mammal Protection Act (n. 4 above), Sec. 1381a. "No later than February 1, 1991, the Secretary shall publish in the Federal Register for public comment a suggested regime that, if authorized by further action of the Congress, would govern the incidental taking of marine mammals by commercial fishermen. . . In determining permissible levels of take, the Secretary should consider the economic and social, as well as the biological impacts, of the proposed regime" (Senate Report No. 100-592 [n. 31 above]).

47. National Marine Fisheries Service, Proposed Regime (n. 34 above), p. 54.

48. Ibid., pp. 54-56.

49. Ibid., p. 10.

50. Ibid., pp. 12-14, 18 .

51. Members include the Alaska Groundfish Data Bank, Aleutians East Borough, American Factory Trawler Association, American High Seas Fisheries Association, American Seafood Harvesters Association, Animal Protection Institute, Arctic Alaska 
Community Negotiated Proposal for a Marine Mammal Research and Conservation Program to be Enacted through the Marine Mammal Protection Act Reauthorization of 1993." Their proposed management scheme is designed to "recover stocks to OSP and expedite reduction in lethal take to insignificant levels approaching a zero mortality and serious injury rate, and to take aggressive and quick action to avoid the point at which the marine mammal must be listed as 'threatened or endangered' under the ESA or designated depleted under the MMPA and, additionally, to ensure that fishing interactions do not significantly retard recovery." ${ }^{25}$ Their proposal, like that of the NMFS, appropriately attempts to identify and focus immediate management attention on those fisheries where interaction is highest and/or the marine mammal stocks are in the most critical state. Unlike the NMFS, however, the Negotiating Group proposes strict and for the most part unrealistic schedules for implementing their proposal. For example, the NMFS would have only 45 days to consult with the Marine Mammal Commission, Fish and Wildlife Service, affected states and Native Americans, fishery management councils, and other scientists (including scientific representatives of conservation and fishing groups) and publish a preliminary stock assessment of all marine mammal populations occurring in U.S. waters. The public would then have 30 days to comment. Fifteen days following the end of public comment, the NMFS would be bound to publish its final rules. ${ }^{53}$ Unfortunately, these abbreviated deadlines ignore political realities and are based on an erroneous assumption that consensus exists regarding the quality of the data and the means of adequately analyzing and drawing conclusions from such data.

The NMFS also would be required to use the Negotiating Group's decision matrix in determining the stock status. ${ }^{54}$ This decision matrix has its

Fisheries Corporation/Tyson Seafood Group, Association of Village Council Presidents, Bering Sea Fishermen's Association, Blue Water Fishermen's Association, California Abalone Association, California Gillnetters Association, California Urchin Divers Association, California Urchin Producers Association, Center for Marine Conservation, Concerned Area M, Friends of the Sea Otter, Gulf of Alaska Coalition, Kodiak Island Borough, Maine Gillnetters Association, Maine Sardine Council, National Audubon Society, National Fisheries Institute, New England Fishery Management Council, Northwest Indian Fisheries Commission, Pacific Seafood Processors Association, Pacific States Marine Fisheries Commission, Peninsula Marketing Association, Point Judith Fisheries Cooperative Association, Sea Urchin Processors Association of California, Seafreeze Ltd., the Associated Fisheries of Maine, the Marine Mammal Center, the National Fishmeal and Oil Association, Trout Unlimited, and the World Wildlife Fund.

52. MMPA Negotiating Group, Proposal Addressing Sections of the Marine Mammal Protection Act Negotiations Relevant to Commercial Fishing Interactions (Washington, D.C.), p. 3.

53. Ibid., pp. 7-10.

54. Ibid., p. 8. 
own problems. For example, small populations are identified as those with population estimates below 10,000 animals. This figure ignores critical differences between populations at $1,000-2,000$ and those at 10,000. In addition, under this matrix a species whose estimated population is 1,500 animals and whose fisheries interaction is rated low (i.e., less than $1 \%$ of the population) will not get priority status. Although that $1 \%$ of the population represents only 15 animals, if those animals taken are females or are taken from a breeding stock that is experiencing particular difficulty, the take could significantly retard recovery and even contribute to the species' decline. In addition, such a categorization would make it more difficult for managers to argue for limiting takes when necessary.

A third well-intentioned but defective part of the Negotiating Group's proposal requires the creation of conservation teams whose work would be advisory to the NMFS. The teams would be responsible for reviewing scientific information regarding stocks within a region, identifying problems, recommending mitigation measures necessary to recovery of the species, and developing conservation plans. ${ }^{55}$ These goals are laudable but unlikely to be successful. Although the teams include diverse interests, none is required to have adequate scientific expertise to be able to critically review scientific information. Such a group would be in a better position to advise the NMFS on policy, not on scientific issues. In addition, no funding mechanism is suggested for the costs associated with conservation team meetings. The NMFS has little incentive to expend its limited resources on such teams and has been reluctant to fund meetings of already existing endangered-species recovery teams.

Like the NMFS, the Negotiating Group attempts to integrate the ESA and MMPA as they apply to incidental take in commercial fisheries. The Negotiating Group proposes that ESA-listed marine mammal stocks with established recovery teams would lose MMPA protection, ${ }^{56}$ leaving the ESA as the sole mechanism for authorizing incidental takes. This part of the proposal scores high on efficiency grounds. However, it arguably reduces the level of protection afforded marine mammals, as the MMPA is designed to deal with problems specifically associated with marine mammal populations. For example, the ESA consultation process can result in a decision to sacrifice a species in order to promote other national goals. The MMPA allows no such tradeoffs. Of the fewer than five species that have achieved delisted status under the ESA, one was a marine mammal, the gray whale, that enjoyed simultaneous MMPA protection.

Other Negotiating Group proposals include use of the pre-1988 MMPA general permits and small-take authorizations for all species at OSP, establishment of a separate general authorization process for all other incidental takes

55. Ibid., pp. 10-13.

56. Ibid., p. 6. 
that would preclude intentional lethal takes, establishment of a scientific evaluation working group (which sounds suspiciously duplicative of the Marine Mammal Commission), a 6-year reauthorization period with an intermediate 3 -year progress review, and a discretionary monitoring program. ${ }^{57}$

\section{SOME REAL-WORLD INTERACTIONS}

Nonmarine Mammal Incidental Takes and By-catch of Nontargeted Fish

Commercial fishing operations involve the incidental take of ESA-designated nonmarine mammal species, such as endangered sea turtles incidentally taken by shrimpers and other trawlers. After some vigorous struggles before Congress, courts, and agencies (and during field enforcement efforts), the federal requirement for the use of turtle-excluder devices (or trawl-efficiency devices; TEDs) has finally turned into a relative success story in incidental-take reduction. Furthermore, TEDs are being viewed more broadly as a device for reducing the by-catch of nontargeted fish species and other species not protected by either the MMPA or the ESA, and increasing vessel fuel efficiency. ${ }^{58}$ Under MFCMA Section 304(g), a 3-year shrimp by-catch study report is due soon from the secretary of commerce to the Senate Commerce and House Merchant Marine Committees.

\section{Food-Chain Interactions}

Another important issue is what we call the food-chain interaction. Fish make up a varying proportion of the diet of marine mammals, including the threatened Steller sea lion, which feeds on the commercially valuable pollack fish. Steller sea lion populations in the North Pacific have declined dramatically: is the commercial harvest of pollack a contributing cause to this population decline? Greenpeace unsuccessfully sought to force greater consideration of this question in the management of the pollack fishery in Greenpeace v. Frank$\operatorname{lin}^{59}$ The appointment of a Greenpeace representative to the North Pacific Fishery Management Council's Advisory Panel could lead to greater recognition of broader ecosystem concerns in the fishery management plans generated by that and other councils under the MFCMA. Such an approach is especially likely where ESA-designated species such as the Steller sea lion are involved.

57. Ibid., pp. 5, 9, 13, 16-17.

58. See Louisiana v. Verity, 853 F. 2d 322 (5th Cir. 1988).

59. 982 F, 2d 1342 (9th Cir. 1992). 
Increasing Impacts of ESA Designations on Commercial and Recreational Fishing

To date the ESA's principal impacts on fishing have come through the act's federal agency consultation requirements and incidental-take restrictions protecting endangered marine mammals and turtles, rather than critical habitat designations or recovery-plan implementation (or conservation-plan implementation under the MMPA). For example, the ESA consultation process resulted in the 3- to 10-mile expansion of buffer zones surrounding Steller sea lion rookeries, in which fishing is prohibited ${ }^{60}$ Critical habitat designations and implementation of the December 1992 final recovery plan for the Steller sea lion could involve even greater impacts on fishing. ${ }^{61}$

Aside from endangered marine mammals and sea turtles, the ESA has until recently not significantly affected commercial and recreational fishing. ${ }^{62}$ Furthermore, the testimony in the ESA reauthorization process so far has focused on the act's landside impacts on such activities as commercial forestry and commercial and residential land development. But in the Pacific Northwest, the act can be expected to have significant impacts on commercial and recreational salmon fishing due to the recent ESA listings of certain Snake and Sacramento River salmon species, and the possible listings of coastal coho salmon species.

With some commercially and recreationally valuable salmon species listed as endangered or threatened, and the problems created by the intermingling of unlisted wild and hatchery salmon with the listed wild species, a broad spectrum of harvest and incidental-take activities is being scrutinized under the ESA ${ }^{63}$ Under ESA Section 7, federal fishery managers must avoid jeopardizing the continued existence of the listed salmon species, and both federal and nonfederal actors are subject to ESA Section 9's taking prohibitions. Thus, federal dam operators who affect the upstream and downstream migrations of salmon have Section 9 as well as Section 7 obligations, with nonfederal actors such as irrigation water diverters being subject to Section $9 .{ }^{64}$

60. See American Factory Trawler Association v. Knauss, No. C92-870R (W.D. Wa. 24 July 1992); Federal Register 58 (1993): 16369; Code of Federal Regulations, vol. 50, Pt. 227. 226.12 .

61. See Federal Register 58 (1993): 17181; Code of Federal Regulations, vol. 50, Sec.

62. See Oliver Houck, "The Endangered Species Act and Its Implementation by the U.S. Departments of Interior and Commerce," Colorado Law Review 64 (1993): 277.

63. See, e.g., Pacific Northwest Generating Cooperative v. Brown, 1993 W.L. 122001 (D. Or.).

64. See United States v. Glenn-Colusa Irrigation District, 758 F. Supp. 1126 (1992) (irrigation pumping enjoined during migration of threatened salmon). 
Implementation of Sections 7 and 9 is aided but not dependent upon critical habitat designation and recovery-plan preparation under ESA Section 4. While economic factors are not supposed to affect listing decisions, the ESA allows their consideration in the designation of critical habitat. For endangered and threatened Snake River salmon species, the proposed designated critical habitat includes the Columbia and Snake Rivers and their tributaries. ${ }^{65}$ Thus, activities ranging from forestry and agriculture to urban development within that habitat become reviewable under the ESA. Given the multiple factors adversely affecting the survival of the listed Snake River species, the effort to prepare and implement a successful recovery plan will be challenging. A key consideration will be determining the appropriate roles for the Northwest Power Planning Council's Columbia Basin Fish and Wildlife Program. Until recovery occurs, salmon fisheries management throughout the region and extending north past British Columbia to Alaska will be significantly affected.

The recent proposed listing of the San Francisco Bay Delta smelt could have similar repercussions for a broad array of resource users in central California. ${ }^{66}$

\section{CONCLUSIONS}

What alternatives for integrating living resources management under the MMPA, ESA, and MFCMA are workable and politically feasible? Several regional fishery management councils now routinely prepare multispecies fishery management plans (FMPs). One can consider the Pacific Fishery Management Council's multispecies groundfish plan as a model under the existing MFCMA framework: it covers multiple species of groundfish; acknowledges and tries to deal with overfishing and overcapitalization through a limited entry scheme (not individual transferable quotas [ITQs]) that was added by Amendment 6 to the plan and will commence in 1994; deals with problems of salmon by-catch in proposed Amendment 7; and explicitly acknowledges the council's responsibilities to comply with the MMPA, the ESA, and the federal Coastal Zone Management Act's federal consistency provision and other required federal signoffs.

With adequate budget and personnel, the preparation of ecosystem plans by some of the more capable councils would seem to be feasible. Such plans would be an extension of the councils' own proposal as part of the MFCMA reauthorization process that FMPs be required to designate habitat essential

65. See Federal Register 57 (1992): 57051; Code of Federal Regulations, vol. 50, Sec. 226.12. Pt. 17.

66. See Federal Register 58 (1993): 12854; Code of Federal Regulations, vol. 50, 
to achieving optimum yield of a species or species complex, which in turn is said to be similar to a NMFS staff draft proposal. To support more sophisticated planning, the councils and some segments of the fishing industry support amending the MFCMA to allow the councils to collect fees to help pay the costs of management.

Separately from the MFCMA, the NMFS is proceeding to integrate some of its roles under the MMPA and ESA, for example, through its October 1992 combined guidelines covering both ESA Section 4 recovery plans and MMPA Section 115 conservation plans for depleted marine mammals. Are these NMFS-combined recovery-planning guidelines for ESA-designated species and depleted marine mammals, multispecies ecosystem plans prepared by the MFCMA councils, and the MFCMA council's proposed habitat amendments to the MFCMA adequate responses to the need for more holistic approaches to U.S. natural resources management and U.S. fulfillment of its international biodiversity commitments? Probably not, but their implementation would be a definite improvement over the current situation.

On the terrestrial side, holistic resource management in the United States is complicated by extensive private ownership of land. But as our paper demonstrates, even on the marine side where that factor is not present, significant difficulties exist due to the mobility of the marine species of concern, the fluid nature of their environment, the mixed record of the federal agencies charged with their protection and management, and congressional inability to legislate in other than a piecemeal fashion. 